\title{
PENERAPAN MODEL PEMBELAJARAN \\ TEAM ASSISTED INDIVIDUALIZATION BERBANTUAN MODUL UNTUK MENINGKATKAN KEMAMPUAN MEMORI DAN PRESTASI BELAJAR SISWA PADA MATERI HIDROKARBON KELAS X1 SMA ISLAM 1 SURAKARTA TAHUN PELAJARAN 2016/2017
}

\author{
Choiria Shinta ${ }^{*}$, Widiastuti Agustina Eko S, dan Sulistyo Saputro \\ Program Studi Pendidikan Kimia, FKIP,Universitas Sebelas Maret, Surakarta, Indonesia \\ *Keperluan korespondensi, telp: 085728877445 email: choiriashinta1995@gmail.com
}

\begin{abstract}
ABSTRAK
Penelitian ini bertujuan untuk meningkatkan kemampuan memori dan prestasi belajar siswa kelas X1 SMA Islam 1 Surakarta pada materi hidrokarbon dengan menerapkan model pembelajaran Team Assisted Individualization (TAI) berbantuan modul. Penelitian ini merupakan penelitian tindakan kelas yang terdiri dari dua siklus, dengan tiap siklus terdiri dari perencanaan, pelaksanaan tindakan, observasi, dan refleksi. Subyek penelitian adalah siswa kelas X1 SMA Islam 1 Surakarta tahun pelajaran 2016/2017. Data diperoleh melalui observasi, tes, angket, dan wawancara. Teknik analisis data yang digunakan adalah analisis deskriptif kualitatif. Hasil penelitian menunjukkan bahwa kemampuan memori siswa meningkat dari prasiklus sebesar $41 \%$ menjadi $52 \%$ pada siklus I dan $74 \%$ pada siklus II. Kemudian prestasi belajar siswa dapat dilihat dari aspek kognitif, afektif, dan psikomotor. Pada siklus I ketuntasan belajar aspek kognitif sebesar $40,74 \%$ meningkat menjadi $66,67 \%$ pada siklus II dari target $60 \%$. Persentase aspek afektif siklus I sebesar $92,59 \%$ dari target $70 \%$, sedangkan aspek psikomotor pada siklus I sebesar $100 \%$ dari target $60 \%$. Kesimpulan penelitian ini adalah penerapan model pembelajaran Team Assisted Individualization (TAl) berbantuan modul dapat meningkatkan kemampuan memori dan prestasi belajar siswa pada materi hidrokarbon kelas X1 SMA Islam 1 Surakarta tahun pelajaran 2016/2017.
\end{abstract}

Kata kunci : hidrokarbon, kemampuan memori, penelitian tindakan kelas, prestasi belajar, TAI

\section{PENDAHULUAN}

\section{Pemerintah}

mengupayakan peningkatan mutu pendidikan dengan melakukan perubahan kurikulum. Salah satu kurikulum pembelajaran yang digunakan di Indonesia adalah Kurikulum Tingkat Satuan Pendidikan. Kurikulum Tingkat Satuan Pendidikan (KTSP) telah ditetapkan dalam PP Nomor 19 tahun 2005 Pasal 1 Ayat 15 sebagai kurikulum operasional yang disusun oleh dan dilaksanakan di masing-masing satuan pendidikan. Kurikulum KTSP, memberi kesempatan guru untuk mengembangkan indikator pembelajaran yang akan disampaikan di sekolah sesuai dengan kemampuan diri siswa.
SMA Islam 1 Surakarta merupakan salah satu satuan pendidikan di Surakarta yang masih menggunakan KTSP. Berdasarkan hasil observasi peneliti pada bulan September 2016, secara umum kegiatan pembelajaran kimia di SMA ini tergolong konvensional, pembelajaran masih didominasi oleh guru (teacher centered learning). Kondisi lapangan menunjukkan bahwa siswa SMA Islam 1 Surakarta masih merasa sulit dalam menerima materi kimia yang diajarkan terutama bila berhubungan dengan hafalan dan pemahaman konsep. Berdasarkan hasil wawancara dengan guru kimia di SMA diketahui bahwa materi pembelajaran kimia dianggap masih sulit dipelajari oleh siswa 
karena sebagian yang dipelajari bersifat abstrak, yaitu apa yang dipelajari tidak bisa dilihat oleh kasat mata. Selain itu, mata pelajaran kimia belum dipelajari secara khusus di tingkat Sekolah Menengah Pertama (SMP) sehingga siswa masih merasa sulit memahami saat menerima materi yang disampaikan oleh guru. Hal ini menyebabkan prestasi belajar kimia rendah atau belum mencapai target yang diinginkan.

Berdasarkan nilai Ujian Akhir Semester Ganjil 2016/2017 di kelas X, diperoleh data bahwa kedua kelas memiliki prestasi belajar kimia rendah dengan ketuntasan yang sangat kecil sebagaimana disajikan pada Tabel 1. Berdasarkan pertimbangan kondisi kelas $\mathrm{X}$, dimana siswa kelas X2 sangat sulit dikondisikan sedangkan kelas $\mathrm{X} 1$ cenderung bisa dikondisikan oleh guru saat pembelajaran, maka dipilihlah siswa kelas X1 sebagai subjek penelitian.

Tabel 1. Rata-Rata Nilai Ulangan Akhir Semester Gasal Kelas X

\begin{tabular}{cccc}
\hline Kelas & KKM & $\begin{array}{c}\text { Jumlah } \\
\text { Siswa }\end{array}$ & $\begin{array}{c}\text { Ketuntasan } \\
(\%)\end{array}$ \\
\hline X1 & 68 & 27 & 14,81 \\
X2 & 68 & 25 & 8 \\
\hline
\end{tabular}

Prestasi belajar siswa tidak hanya dipengaruhi oleh faktor eksternal, tetapi juga dipengaruhi oleh faktor internal, salah satunya adalah kemampuan memori. Memori mencakup mencamkan, menyimpan, dan memproduksi kembali kesan-kesan [1]. Kemampuan memori sangat dibutuhkan seseorang, terutama dalam kegiatan belajar. Segala macam belajar melibatkan ingatan, tanpa ingatan seseorang tidak dapat mengingat sesuatu mengenai pengalamannya. Tanpa adanya ingatan/kemampuan memori terhadap materi pembelajaran, dimungkinkan siswa tidak akan memahami dan mengemukakan kembali isi materi yang pernah disampaikan oleh guru.

Materi hidrokarbon penting sebagai dasar dalam mempelajari kimia. Karakteristik materi kimia ada yang kualitatif (hafalan) dan kuantitatif (perhitungan). Hidrokarbon masuk dalam kualitatif. Materi hidrokarbon merupakan salah satu materi kimia kelas $X$ semester genap yang dianggap membosankan dan sulit oleh siswa SMA Islam 1 Surakarta karena sifatnya yang hafalan. Hal ini dibuktikan dengan materi pada semester sebelumnya yang karakterisktik yaitu tentang penamaan senyawa dimana siswa memiliki nilai rata-rata nilai ulangan harian dibawah KKM dan berdasarkan wawancara dengan guru materi hidrokarbon dianggap cukup sulit bagi siswa SMA Islam 1 Surakarta. Materi hidrokarbon bersifat abstrak dan di dalamnya memerlukan hafalan. Hal ini erat kaitannya dengan kemampuan memori yang dimiliki oleh siswa. Peneliti juga telah melakukan tes kemampuan memori pada tahap prasiklus dan didapatkan hasil hanya $41 \%$ siswa memiliki kemampuan memori tinggi. Hasil tersebut memperkuat dugaan bahwa salah satu penyebab rendahnya prestasi belajar pada materi hidrokarbon adalah kemampuan memori yang rendah.

Salah satu cara untuk mencapai kualitas pendidikan yang lebih baik adalah dengan memperhatikan proses pembelajaran pada lingkup sekolah. Pemilihan model yang tepat dalam menyajikan suatu materi kimia dapat membantu siswa menyerap materi dengan lebih mudah. Model pembelajaran kooperatif mampu mengurangi dominasi guru dalam kelas dan membuat siswa lebih aktif. Pembelajaran kooperatif merupakan bentuk pembelajaran dengan cara siswa belajar dan bekerja dalam kelompok-kelompok kecil secara kolaboratif yang anggotanya terdiri dari empat sampai enam orang dengan struktur kelompok yang bersifat heterogen [2]. Model pembelajaran ini menuntut siswa memiliki dua tanggung jawab, yaitu mereka belajar untuk dirinya sendiri dan juga membantu sesama anggota kelompok. Sebuah penelitian mendapatkan hasil bahwa pembelajaran kooperatif dapat meningkatkan prestasi belajar siswa [3].

Kelas X1 SMA Islam 1 Surakarta memiliki beberapa siswa yang unggul di dalam kelas. Perbedaan intelegensi siswa dapat memengaruhi cepat 
lambatnya siswa dalam menyerap materi pelajaran. Siswa yang dianggap unggul diharapkan mampu membantu siswa yang lambat dalam belajar. Oleh karena itu, model pembelajaran kooperatif yang cocok digunakan pada pembelajaran kimia materi hidrokarbon pada penelitian ini adalah pembelajaran kooperatif model Team Assisted Individualization (TAI). Tujuan pembelajaran TAl adalah mengatasi kesulitan pemahaman serta memecahkan permasalahan materi pembelajaran secara bersama dengan ketua kelompok (asisten) yang memiliki kemampuan pengetahuan yang lebih tinggi. Keberhasilan individu pada model pembelajaran ini merupakan keberhasilan kelompok sehingga akan mendorong setiap anggota kelompok untuk memperjuangkan keberhasilan kelompoknya dan dengan adanya bantuan dari teman dalam proses pembelajaran, seorang individu bisa mendalami suatu materi dengan lebih mudah.

Selain pemilihan model pembelajaran, media pembelajaran merupakan salah satu komponen yang cukup penting dalam pembelajaran. Penggunaan media pembelajaran membantu guru dalam menyampaikan materi pelajaran kepada siswanya, agar pesan yang disampaikan bisa lebih mudah dimengerti dan lebih menarik bagi siswa. Salah satu media pembelajaran yang cocok diterapkan untuk membantu pembelajaran model TAl adalah modul. Modul adalah sebuah buku yang ditulis dengan tujuan agar peserta didik dapat belajar secara mandiri tanpa atau dengan bimbingan guru [4]. Modul ini menjadi sumber belajar dan alat penunjang pembelajaran individual dalam melaksanakan pembelajaran model TAl, sehingga proses pembelajaran akan lebih efektif efisien.

Sebagai tindak lanjut dari permasalahan yang telah dikemukakan diatas, maka perlu dilakukan penelitian tindakan (action research) yang berorientasi pada peningkatan efektifitas pembelajaran melalui Penelitian Tindakan Kelas (PTK). Peneliti melakukan penelitian untuk meningkatkan kualitas pembelajaran khususnya kemampuan memori dan prestasi belajar siswa pada kelas $\mathrm{X} 1$ SMA Islam 1 Surakarta dengan menggunakan model pembelajaran kooperatif tipe Team Assisted Individualization (TAI) berbantuan modul. Keunggulan dari pembelajaran TAI berbantu modul yaitu menerapkan pembelajaran yang berpusat pada siswa dan bimbingan antarteman dimana modul berperan sebagai penyedia informasi dasar dan sebagai bahan pembelajaran bagi siswa. Pada metode TAl terdapat seorang siswa yang berperan sebagai asisten yang bertugas membantu siswa yang kurang mampu secara individual dalam kelompoknya. Adanya teman sebaya yang bertugas membantu guru menjelaskan, siswa tidak takut untuk banyak bertanya pada temannya yang bertindak sebagai asisten apabila merasa kurang paham dalam mengerjakan soal diskusi. Selain itu, siswa dapat berlatih bekerjasama untuk menyelesaikan masalah, sehingga disini siswa tidak hanya mengharapkan bantuan dari guru saja. Hal ini dapat mengasah memori siswa sehingga nantinya dalam mempelajari suatu hal bisa lebih mudah untuk memahaminya. Akhirnya, pembelajaran TAI berbantuan modul dapat membantu siswa dalam meningkatkan kemampuan memori dan prestasi belajar siswa pada mata pelajaran kimia khususnya materi hidrokarbon.

\section{METODE PENELITIAN}

Penelitian ini merupakan Penelitian Tindakan Kelas (PTK) yang dilaksanakan selama 2 siklus. Setiap siklus terdiri dari tahap perencanaan (planning), pelaksaan (action), observasi (observation), dan refleksi (reflection).

Subjek penelitian adalah siswa kelas X1 SMA Islam 1 Surakarta tahun pelajaran 2016/2017. Pemilihan subjek didasarkan pertimbangan bahwa subjek tersebut mempunyai permasalahan yang telah teridentifikasi. Instrumen pembelajaran meliputi silabus, RPP dan modul. Instrumen penilaian meliputi aspek kognitif, afektif, psikomotor dan kemampuan memori. 
Teknik pengumpulan data dengan tes, angket, observasi, wawancara, dan kajian dokumen. Data yang dikumpulkan meliputi data informasi tentang keadaan siswa dilihat dari aspek kualitatif dan kuantitatif. Aspek kualitatif adalah data lapangan yang menggambarkan proses belajar mengajar di kelas. Aspek kuantitatif berupa data penelitian prestasi siswa pada materi hidrokarbon yang meliputi nilai yang diperoleh siswa dari tes kognitif, angket afektif, dan tes kemampuan memori siswa terhadap pembelajaran baik siklus I maupun siklus II.

Analisis data dimulai dari awal pengambilan data sampai berakhirnya pengumpulan data. Teknik analisis data dengan deskriptif kualiatif. Teknik analisis data secara kualitatif mengacu pada model analisis Miles dan Huberman yang dilakukan dalam tiga komponen yaitu reduksi data, penyajian data, dan penarikan kesimpulan/ verifikasi [5].

\section{HASIL DAN PEMBAHASAN}

\section{Siklus I}

Tahap perencanaan siklus I meliputi penyusunan instrumen pembelajaran dan instrumen penilaian. Instrumen pembelajaran berupa silabus, RPP dan modul sedangkan instrumen penilaian meliputi kemampuan memori dan prestasi belajar aspek kognitif, afektif dan psikomotor.

Pembelajaran siklus 1 dialokasikan 6 jam pelajaran yaitu $5 \times 45$ menit untuk penyampaian materi dan $1 \times 45$ menit untuk evaluasi. Pertemuan pertama, guru memberi pengarahan tentang sistem yang akan dilaksanakan yaitu pembelajaran menggunakan model Team Assisted Individualization (TAI) dilengkapi modul. Guru memberikan apersepsi kepada siswa dengan mereview kembali materi yang telah diajarkan sebelumnya. Guru memberikan orientasi dan juga memotivasi siswa agar siswa bersemangat mengikuti pembelajaran.

Pada kegiatan inti, pembelajaran dibagi menjadi tiga tahap yaitu eksplorasi, elaborasi, dan konfirmasi yang disesuaikan dengan sintak model pembelajaran TAl. Pada tahap eksplorasi, siswa didistribusikan ke dalam kelompok-kelompok kecil heterogen. Setiap kelompok memiliki asisten yang bertanggungjawab untuk membantu rekan satu timnya dalam menguasai materi hidrokarbon. Asisten dipilih dari siswa yang memiliki nilai tertinggi dari ujian-ujian sebelumnya (placement test). Jumlah siswa kelas X1 ada 27 siswa dan dibagi menjadi 6 kelompok dimana setiap kelompoknya terdiri dari 4-5 siswa (teams). Untuk menghindari adanya miskonsepsi dalam penyampaian materi dari asisten ke anggota kelompoknya, asisten diberikan pembekalan terlebih dahulu dihari sebelumnya di luar jam pelajaran. Siswa juga difasilitasi terjadinya interaksi antarsiswa, serta antara siswa dengan guru, lingkungan, dan sumber belajar lainnya pada bahasan hidrokarbon (teaching group). Selain itu, siswa mencari informasi tentang materi hidrokarbon dengan membaca modul yang telah dipersiapkan oleh guru atau dari sumber lain (student creative).

Pada tahap elaborasi, siswa berdiskusi dalam kelompok tentang permasalahan berupa soal diskusi yang terdapat di dalam modul (team study). Apabila ada anggota kelompok yang mengalami kesulitan dalam mengerjakan tugas dapat meminta bimbingan kepada teman yang ditunjuk sebagai asisten. Guru berperan sebagai fasilitator dan mengarahkan siswa dalam menyelesaikan permasalahan yang terdapat pada modul. Siswa menyajikan hasil diskusi kelompok di depan kelas dan siswa dari kelompok lain ikut menanggapi presentasi tersebut dengan cara memberi pertanyaan atau masukan kepada kelompok tersebut. Pada tahap konfirmasi, siswa diberi penguatan dan umpan balik positif dalam bentuk lisan maupun tulisan tentang hasil pembelajaran yang telah berlangsung. Hal ini dilakukan supaya tidak terjadi miskonsepsi mengenai materi yang didiskusikan.

Pada kegiatan penutup, guru memberikan post test kepada siswa yang dikerjakan secara individu sebagai 
evaluasi (fact test). Soal post test yang ada di dalam modul dikerjakan mandiri untuk mengetahui sejauh mana kemampuan siswa dalam memahami materi yang telah disampaikan. Nilai post test dan nilai hasil diskusi tidak digunakan dalam proses perhitungan aspek kognitif, tetapi hanya digunakan untuk mengetahui pemahaman siswa pada sub materi yang sudah dibahas. Meski begitu, nilai yang didapat dipaparkan dan nilai yang tinggi akan diberi penghargaan (team score and team recognition). Selanjutnya siswa dibimbing guru untuk menyampaikan kesimpulan dari pembelajaran yang telah dilakukan (whole class units). Pada kegiatan akhir, guru menyampaikan sub materi yang akan dipelajari selanjutnya yang bertujuan agar siswa mempunyai gambaran tentang materi yang akan dipelajari. Pertemuan kedua dan ketiga dilakukan proses pembelajaran seperti pada pertemuan pertama. Pertemuan keempat diadakan tes evaluasi siklus I untuk aspek kognitif dengan 25 butir soal pilihan ganda selama 45 menit. Selain itu diadakan pula tes kemampuan memori dengan 30 butir soal objektif dan penilaian aspek afektif dengan 30 soal.

Tabel 2. Ketercapaian Target Keberhasilan Siklus I

\begin{tabular}{cccc}
\hline Aspek & $\begin{array}{r}\text { Tar- } \\
\text { get } \\
(\%)\end{array}$ & $\begin{array}{c}\text { Capai- } \\
\text { an (\%) }\end{array}$ & Kriteria \\
\hline Kognitif & 60 & 40,74 & Belum Tercapai \\
Afektif & 70 & 92,59 & Tercapai \\
Psikomotor & 60 & 100 & Tercapai \\
K. Memori & 60 & 52 & Belum Tercapai \\
\hline
\end{tabular}

Berdasarkan keseluruhan hasil yang diperoleh pada siklus I, aspek kognitif dan kemampuan memori belum mencapai target yang ditentukan. Ketercapaian aspek kognitif tiap indikator disajikan pada Tabel 3.

Tabel 3. Ketercapaian Aspek Kognitif Tiap Indikator pada Siklus I

\begin{tabular}{|c|c|c|c|}
\hline No & Indikator & $\begin{array}{c}\text { Capaian } \\
(\%)\end{array}$ & $\begin{array}{lc}\text { K } & \text { Nomor } \\
\text { e } & \text { Tidak } \\
\text { t } & \text { Tercapai }\end{array}$ \\
\hline 1 & $\begin{array}{l}\text { Mengelompokkan } \\
\text { senyawa } \\
\text { hidrokarbon }\end{array}$ & 73,50 & $\sqrt{ } 7$ \\
\hline
\end{tabular}

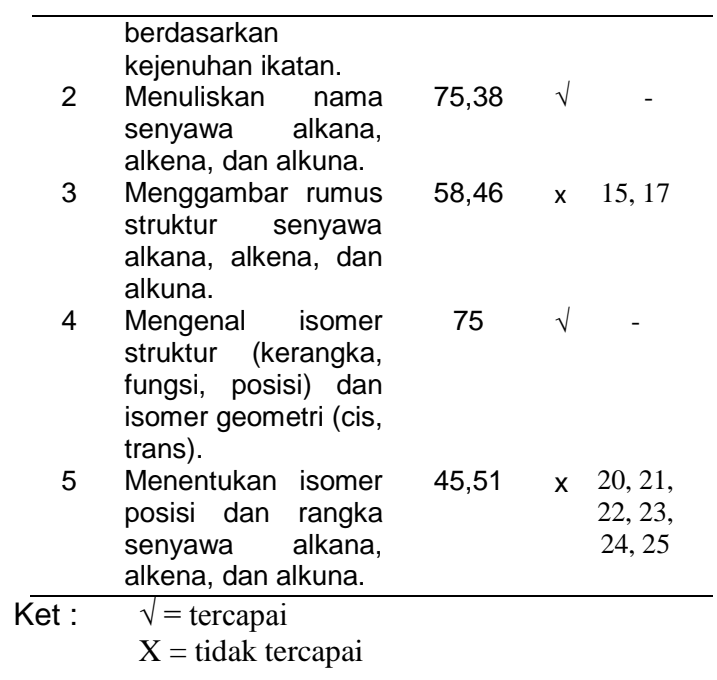

Aspek kognitif yang belum dikuasai siswa ada pada penggambaran rumus struktur dan penentuan isomer alkana, alkena, dan alkuna. Indikator yang tidak tuntas disebabkan oleh karakteristik materi yang kompleks, yaitu menerapkan seluruh konsep dari penamaan senyawa hidrokarbon hingga perubahannya menjadi senyawa lain. Hal inilah yang membuat siswa kesulitan menghadapi soal dengan IK tersebut. Butir soal yang belum memenuhi target ada pada nomor: 15 : menggambarkan rumus struktur rantai bercabang alkana, ketercapaian 38\%.

17 : menggambarkan rumus struktur rantai bercabang alkana dan alkuna, ketercapaian 35\%.

20 : menyebutkan jumlah isomer suatu alkena, ketercapaian 35\%.

21 : menyebutkan jumlah isomer suatu alkana, ketercapaian $46 \%$.

22 : menunjukkan senyawa yang bukan isomer dari suatu alkana, ketercapaian $58 \%$.

23 : menunjukkan senyawa yang bukan isomer dari suatu alkena, ketercapaian 35\%.

24 : menunjukkan senyawa yang bukan isomer dari suatu alkuna, ketercapaian $42 \%$.

25 : memasangkan senyawa alkena yang merupakan isomer jika diketahui rumus strukturnya, ketercapaian $58 \%$.

Meskipun secara umum IK 1 sudah memenuhi target capaian lebih dari $60 \%$, namun ada 1 dari 9 butir soal pada IK1 
yang belum tuntas yaitu pada nomor 7 dengan indikator soal menggambarkan struktur senyawa hidrokarbon berdasarkan kejenuhannya dengan ketercapaian yang diperoleh $46 \%$.

Pada dasarnya, tes kognitif dilakukan untuk mengetahui seberapa banyak informasi tentang konsep-konsep kimia yang telah mereka pahami. Semakin tinggi tingkat kemampuan memori siswa akan semakin banyak informasi yang dapat diingat dan pada akhirnya akan semakin banyak pula konsep yang dipahami. Siswa yang memiliki kemampuan memori tinggi akan lebih mudah menghafal, menyimpan dan menjawab soal kognitif dibanding siswa yang memiliki kemampuan memori rendah. Dari rataan prestasi kognitif siswa menunjukkan prestasi siswa yang mempunyai kemampuan memori tinggi lebih baik dari siswa yang mempunyai kemampuan memori rendah.

Aspek afektif mencakup sikap siswa dalam menyikapi permasalahan yang sedang dihadapi sehingga prestasi afektif siswa lebih dipengaruhi oleh faktor internal siswa seperti sikap, nilai, moral, konsep diri dan minat siswa terhadap materi pelajaran, metode pembelajaran, guru dan siswa lain [6]. Prestasi belajar aspek psikomotor dinilai berdasarkan observasi dengan indikator berupa persiapan, pelaksanaan, penyimpulan, dan penggunaan waktu dalam berdiskusi. Aspek afektif dan psikomotor ini bisa memenuhi target karena apabila guru melihat ada hal yang kurang pada siswa, maka guru akan menyampaikan hal yang kurang untuk ditingkatkan. Adanya pembenahan setiap adanya kekurangan pada aspek afektif dan psikomotor ini menjadi salah satu pemicu terjadinya kenaikan hasil penilaiannya.

Pada saat berlangsungnya pembelajaran pada siklus I, beberapa siswa sudah menunjukkan keaktifan mereka dalam hal bertanya beberapa bagian dari materi yang belum jelas. Namun demikian, keaktifan siswa belum menyeluruh. Masih ada sebagian kecil siswa yang belum menunjukkan keaktifannya dalam mengikuti pembelajaran dan ikut dalam pemecahan permasalahan dengan kelompoknya.
Terdapat pula kelompok diskusi yang belum terbimbing dengan baik karena adanya asisten yang belum berkompeten. Kurang optimalnya peran asisten menyebabkan perolehan prestasi belajar tim rendah. Sebagai tindak lanjutnya maka diberikan pembekalan yang lebih mendalam kepada asisten masingmasing kelompok.

Berdasarkan keseluruhan hasil yang diperoleh pada siklus I, peneliti mengadakan tindakan lebih lanjut yaitu dengan melakukan pembelajaran di siklus II khususnya pada dua indikator yang belum tercapai pada aspek kognitif dan juga meningkatkan kemampuan memori siswa sehingga mampu mencapai target yang telah ditentukan.

\section{Siklus II}

Berdasarkan hasil refleksi pada siklus I perlu dilakukan perencanaan untuk pelaksanaan tindakan pada siklus II untuk memperbaiki kendala-kendala yang terdapat pada siklus I. Materi yang diberikan pada pembelajaran siklus II difokuskan pada indikator kompetensi yang belum tuntas pada siklus $\mathrm{I}$.

RPP siklus II disusun sebanyak 4 JP (2 kali pertemuan), yaitu $3 \times 45$ menit penyampaian materi dan $1 \times 45$ menit untuk evaluasi siklus II. Tindakan yang dilakukan oleh guru antara lain dengan mengubah kelompok diskusi. Guru menegaskan kembali bahwa harus ada interaksi antarsiswa saat berdiskusi, memanfaatkan asisten, dan guru berperan sebagai fasilitator. Guru memberikan perhatian lebih kepada asisten maupun kepada siswa yang mengalami kesulitan pada aspek kognitif siklus I.

Pada akhir pembelajaran siklus II, diadakan evaluasi siklus II. Soal yang diberikan untuk uji aspek kognitif berbentuk pilihan ganda berjumlah 10 butir soal, sedangkan tes kemampuan memori berjumlah 30 butir soal objektif. Hasil analisis kemampuan memori tinggi siswa sebesar $74 \%$ dan aspek kognitif $66,67 \%$. Ketercapaian target keberhasilan siklus II disajikan pada Tabel 4. 
Tabel 4. Ketercapaian Target Keberhasilan Siklus II

\begin{tabular}{cccc}
\hline Aspek & $\begin{array}{c}\text { Target } \\
(\%)\end{array}$ & $\begin{array}{c}\text { Capaian } \\
(\%)\end{array}$ & Kriteria \\
\hline Kognitif & 60 & 66,67 & Tercapai \\
K. Memori & 60 & 74 & Tercapai \\
\hline
\end{tabular}

Secara umum, aspek kognitif siswa telah memenuhi target minimum 60\%. Namun apabila dianalisis setiap butir soalnya, ada satu nomor yang masih dibawah target yaitu nomor 9 dengan indikator menentukan senyawa yang bukan isomer dari suatu alkuna. Soal nomor 9 ini memerlukan analisis yang dalam karena siswa tidak sekedar diminta menggambar struktur dari nama yang disediakan pada option pilihan jawaban, melainkan juga menentukan yang bukan merupakan isomer suatu alkuna dari berbagai pilihan yang ada. Hal inilah yang membuat siswa kesulitan menghadapi soal dengan IK tersebut.

\section{Perbandingan Antar Siklus}

Secara umum pembelajaran yang dilangsungkan di siklus II mempunyai hasil yang lebih baik dibandingkan siklus I. Perbandingan hasil tindakan antarsiklus ditunjukkan pada Gambar 1 dan Tabel 5. Berdasarkan Tabel 5 terjadi adanya peningkatan dari siklus I ke siklus II. Kemampuan memori dan aspek kognitif mencapai target pada siklus II sedangkan target aspek afektikf dan psikomotor telah tercapai pada siklus I. Pada penelitian tindakan kelas, penelitian dikatakan berhasil jika aspek yang diukur mencapai target yang telah ditentukan. Pada penelitian ini dapat disimpulkan bahwa penelitian berhasil karena telah mencapai target pada siklus I maupun siklus II.

Tabel 5. Perbandingan Hasil Antarsiklus

\begin{tabular}{cccc}
\hline \multirow{2}{*}{ Aspek } & \multicolumn{2}{c}{$\begin{array}{c}\text { Ketercapaian } \\
(\%)\end{array}$} & \\
& Siklus & Siklus & \\
& I & II & \\
\hline Kognitif & 40,74 & 66,67 & Meningkat \\
Afektif & 92,59 & - & Tuntas \\
Psikomotor & 100 & - & Tuntas \\
K. Memori & 52 & 74 & Meningkat \\
\hline
\end{tabular}

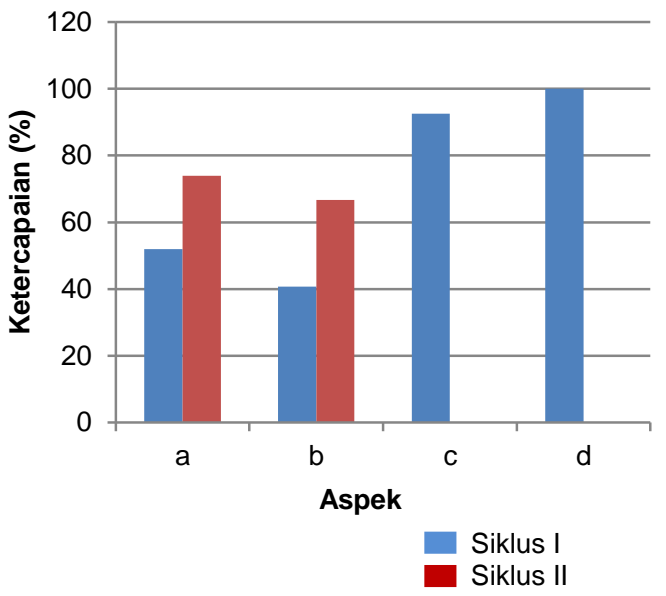

Gambar 1. Perbandingan Hasil Tindakan Antarsiklus

Ket: $\quad \mathrm{a}=$ kemampuan memori

$$
\begin{aligned}
& b=\text { kognitif } \\
& c=\text { afektif } \\
& d=\text { psikomotor }
\end{aligned}
$$

Hasil penelitian ini relevan dengan penelitian mengenai efek model pembelajaran TAl yang memberikan hasil signifikan terhadap prestasi belajar siswa [7]. Selain itu juga telah diadakan penelitian mengenai model pembelajaran TAI dilengkapi modul yang mampu meningkatkan prestasi belajar siswa [8] Hasil penelitian lain juga menyatakan bahwa model pembelajaran TAl yang mampu meningkatkan kemampuan memori dan prestasi belajar siswa pada materi hidrokarbon [9].

\section{KESIMPULAN}

Penerapan model pembelajaran Team Assisted Individualization (TAI) berbantuan modul dapat meningkatkan kemampuan memori dan prestasi belajar siswa pada materi hidrokarbon kelas X1 SMA Islam 1 Surakarta tahun pelajaran 2016/2017.

\section{UCAPAN TERIMA KASIH}

Penulis mengucapkan terima kasih kepada Ibu Dwi Djajanti, S.Pd selaku guru mata pelajaran kimia SMA Islam 1 Surakarta yang telah mengijinkan peneliti untuk mengadakan penelitian di kelasnya. 


\section{DAFTAR RUJUKAN}

[1] Baharuddin, 2007, Psikologi Pendidikan Refleksi Teoritis terhadap Fenomena. Yogyakarta : Ar-Ruzz Media.

[2] Rusman, 2012, Model-model Pembelajaran Mengembangkan Profesionalitas Guru Edisi Kedua. Jakarta: Raja Grafindo Persada.

[3] Dat Tran V., 2014, International Journal of Higher Education, 3 (2), 131-140.

[4] Departemen Pendidikan Nasional, 2008, Panduan Pengembangan Bahan Ajar. Jakarta: Direktorat Pendidikan Sekolah Menegah Atas.
[5] Sugiyono, 2013, Metode Penelitian Pendidikan Pendekatan Kuantitatif, Kualitatif dan $R$ \& $D$. Bandung: Alfabeta Bandung.

[6] Hartono, R., Utomo, S.B., Mulyani, S., 2015, Jurnal Pendidikan Kimia (JPK), 4 (1), 196-203.

[7] Tilaar, A.L.F., 2014, International Journal of Science and Engineering Investigations, 3 (24), 25-29.

[8] Uswatun, A.H., Ashadi, Yamtinah, S., 2016, Jurnal Pendidikan Kimia (JPK), 5 (2), 75-80.

[9] Noor, Z.A., Mulyani, S., Masykuri, M., 2015, Jurnal Pendidikan Kimia (JPK), 4 (2), 130-136. 